\title{
Peranan Masyarakat Adat Petalangan Dalam Mengamalkan Nilai Struktur Adat Berbasis Kearifan Lokal Lingkungan
}

\author{
Muhammad Syafi'i \\ Fakultas Keguruan dan Ilmu Kependidikan, Universitas Riau, Pekanbaru 28131, Indonesia. \\ Email : forsyafii@gmail.com
}

\begin{abstract}
Indonesia's natural resources (SDA) along the equator, from the west to the east are experiencing accelerative, extensive and massive shrinkage. The erosion of natural resources almost does not put forward the concept of sustainable development, it has even entered the areas of indigenous peoples. The loss of land forests, for the people of Petalangan does not only mean losing livelihoods and livelihoods, but more fundamentally is the loss cultural resources. Petalangan Indigenous People in Riau were formerly in the government of the Kampar Kingdom then this kingdom changed its name to the Kingdom of Pelalawan. They live berpuak fathers and tribes. In adapting to the environment, community groups develop environmental wisdom as a result of the abstraction of experience managing the environment. This study aims to analyze the role of the indigenous people Petalangan in applying the values of customary structures based on environmental wisdom. The research method was conducted using qualitative descriptive method. Sources of data selected by purposive and snowball sampling. Data obtained data sourced from primary and secondary data. Data was collected through interviews and observations. From the research it can be concluded that kinship system, ethnic group, institutional structure, legal values, customary norms, sanctions and symbolics play a role in strengthening the local wisdom culture environment because they feel one lineage and in one community that has the same interests, the community feels land, river and the jungle must be guarded because of the common property in accordance with the sense of kinship possessed by the Petalangan community, in customary customs there is a regulation about the use that relates to the environment.
\end{abstract}

Key words: Indigenous people of petalangan, Indigenous structure value, Local environmental

Kekayaan sumberdaya alam (SDA) Indonesia di sepanjang khatulistiwa, mulai dari barat hingga ke timur sedang mengalami penyusutan secara akseleratif, ekstensif, dan masif. Pengikisan SDA tersebut hampir sama sekali tidak mengedepankan konsep pembangunan yang berkelanjutan, bahkan telah memasuki kawasan-kawasan masyarakat adat Hilangnya hutan tanah, bagi masyarakat petalangan bukan saja berarti kehilangan sumber nafkah dan mata pencaharian, tetapi yang lebih mendasar lagi adalah kehilangan sumber budaya. Sumber kegiatan adat dan tradisi, sumber kebanggaan dan harga diri, bahkan kehilangan jati diri dan bagian dari diri mereka sendiri. Sebab, dalam konsep kepercayaan tradisionalnya, alam adalah perlambang diri mereka sendiri dan tempat mereka mendapatkan berbagai jenis bahan untuk kepentingan upacara pengobatan dan sebagainya UNDP (2010).
Masyarakat adat petalangan adalah kelompok masyarakat yang memilki dukungan historis serta keberadaannya tidak diragukan. Menurut tombo, mereka berasal dari Johor mengunakan perahu, dan membuka hutan di pemukiman mereka sekarang ini. Mereka menjadi kawula Kerajaan Kampar yang sekarang lebih dikenal dengan Pelalawan dengan menganut ajaran islam dari peradaban bangsa Arab. Di bawah pemerintahan Kesultanan Pelalawan mereka mendapat pengakuan hak atas wilayah hutan mereka (Hutan Tanah Perbatinan Kurang Satu Tiga Puluh), yang dipimpin oleh kepala adat yang dikenal dengan sebutan batin. Hak perlindungan hukum atas hukum adat dan tanah adat pada masyarakat Petalangan telah mendapat legitmasi.

Orang Melayu Petalangan yaitu suatu komunitas orang melayu Proto di Riau. Masa 
pemerintah orde baru, oleh Departemen Sosial orang Petalangan dikelompokkan ke dalam kelompok masyarakat suku terasing. Istilah suku terasing terkadang disebut juga dengan suku terbelakang atau disebut pula dengan orang pedalaman. Secara berangsung-angsur penyebutan tersebut mengalami penghalusan sehingga sekarang dikenal dengan suku asli. Komunitas orang Petalangan di Riau dahulunya berada dalam pemerintahan Kerajaan Kampar kemudian kerajaan ini berubah nama menjadi Kerajaan Pelalawan. Mereka hidup secara berpuak-puak dan bersuku-suku.Dalam geopolitika Pemerintahan Indonesia, komunitas orang Petalangan terdapat dalam wilayah Kabupaten Pelalawan Provinsi Riau. Sebagian besar wilayahnya merupakan bekas kekuasaan kerajaan Pelalawan. Sampai sekarang orang Petalangan masih tetap mempertahankan sistem kesukuan yang dijaga oleh adat lembaga mereka (Maskar, 2009)

Sistem pengelolaan sumberdaya alam yang telah dikembangkan masyarakat adat maupun masyarakat lokal, sejak lama merupakan muara yang berorientasi pada kesejahteraan masyarakat adat/lokal tersebut, selalu mengedepankan peran serta masyarakat yang berkelanjutan (sustainability). Dalam beradaptasi terhadap lingkungan, kelompokkelompok masyarakat mengembangkan kearifan lingkungan sebagai hasil abstraksi pengalaman mengelola lingkungan. Modal sosial biasanya berbentuk kearifan yang sangat dalam maknanya dan erat kaitannya dengan pranata kebudayaan, terutama pranata kepercayaan (agama) dan hukum adat yang terkadang diwarnai dengan mantra-mantra.

Namun saat ini, sistem tersebut mengalami tekanan-tekanan eksternal, antara lain akibat tidak diakuinya keberadaan masyarakat adat dan lokal dalam sistem pengelolaan sumberdaya alam mereka, dan kebijakan pengelolaan sumber daya alam yang bertumpu pada konsep hak menguasai negara. Tekanan-tekanan tersebut menyebabkan masyarakat adat dan lokal yang sebetulnya merupakan pemilik, pengelola, sekaligus penjaga dan pemelihara sumberdaya alam, menjadi terasing ditanahnya sendiri. Hal tersebut terjadi dikarenakan semakin sempitnya akses masyarakat terhadap sumberdaya alam.

$$
\text { Penelitian ini bertujuan untuk }
$$
menganalisis peranan masyarakat adat Petalangan dalam mengamalkan nilai nilai struktur adat berbasis kearifan lingkungan

\section{BAHAN DAN METODE}

Metode penelitian ini dilakukan dengan menggunakan metode deskriptif kualitatif. Sumber data dipilih secara purposive dan snowball sampling. Data yang diperoleh bersumber dari data primer dan data sekunder. Teknik pengumpulan data dilakukan dengan wawancara dan observasi.

\section{HASIL}

\section{Sistem Kekerabatan}

Orang-orang yang mempunyai hubungan keturunan dan hubungan darah disebut dengan kekerabatan. Secara singkat dapat juga disebutkan bahwa kekerabatan sebagai sistem hubungan yang didasarkan atas perkawinan dan keturunan Dalam pengelompokan umum sistem kekerabatan terbagi atas dua bagian yaitu : Patrilineal dan Matrilineal.

Kelompok-kelompok keluarga seperti ini, ibulah yang menjadi kepala keluarga (matriarchate). Perkawinan antara ibu dengan anak laki-laki di hindari dan di larang. Akibatnya timbullah adat eksogami yaitu hubungan perkawinan diluar diluar kelompoknya sendiri Tingkat yang ketiga terjadi karena laki-laki tidak puas dengan keadaan tersebut, sehingga para laki-laki melakukan hubungan perkawinan perkawinan dengan perempuan kelompok lain, dan membawa perempuan itu masuk kedalam kelompok lakilaki itu sendiri. Anak-anak dari perkawinan seperti ini tinggal dan masuk ke dalam kelompok laki-laki. Timbul kelompok keluarga dimana ayah sebagai kepala keluarga (patriarchate). Mengikuti sistem ini terjadilah pernikahan dalam batas-batas kelompok sendiri.

Sistem kekerabatan yang berlaku dalam Masyarakat Petalangan adalah menganut sistem Patrilinear, artinya seorang anak yang lahir akan dibangsakan kepada suku kaum ayahnya. Disamping itu sistem pergaulan sehari - hari pria dan wanita dibatasi. Seorang pria dan wanita tidak boleh mengadakan pertemuan di tempat yang dianggap tersembunyi seperti di 
lorong - lorong pasar, ladang, dijalan yang dianggap sepi yang sifatnya berduaan dan mereka bukan satu suku (wawancara :M. Yunus Syam, tokoh masyarakat Bandar Petalangan pada tanggal 26 September 2012)

a. Dalam Keluarga :

* Atan, ialah panggilan terhadap kakek dan saudara laki - laki kakek baik dari pihak ayah maupun ibu

* Ino, ialah panggilan terhadap nenek dan saudara nenek baik dari pihak ayah maupun ibu

* Obah, ialah panggilan terhadap ayah

* Mak, panggilan terhadap ibu

* Lung, Panggilan terhadap anak pertama baik laki - laki maupun perempuan

* Nga, Panggilan untuk anak kedua baik laki-laki maupun perempuan

* Udo adalah panggilan untuk anak ketiga baik laki-laki maupun perempuan

* Onsu, ialah panggilan untuk yang yang keempat dan seterusnya baik laki-laki maupun perempuan

b. Dalam Tatanan Masyarakat :

* Datuk, Orang yang menyandang jabatan gelar
Ninik mamak, Orang yang menyandang jabatan dalam kekeluargaan seperti paman dan bibi.

* Moman, Panggilan kepada saudara laki-laki ayah dan saudara laki-laki ibu

* Amai, adalah panggilan untuk ipar perempuan dari ibu

* Nantan, adalah panggilan sayang orang tua kepada anak laki-laki

* Ebut, adalah panggilan sayang orang tua kepada anak perempuan.

\section{Golongan Suku Masyarakat Adat Petalangan}

Secara historis disebutkan bahwa masyarakat Petalangan datang dari Johor mengunakan perahu, dan membuka hutan di pemukiman mereka sekarang ini. Mereka kemudian menjadi kawula Kerajan Kampar. Di bawah pemerintahan Kesultanan Pelalawan mereka mendapat pengakuan hak atas wilayah hutan mereka (Hutan Tanah Perbatinan Kurang Satu Tiga Puluh), yang dipimpin oleh kepala adat yang dikenal dengan sebutan batin. Pada Masyarakat ini memilki 29 Pebatinan, yaitu:

Tabel 1. Nama-Nama Batin di Masyarakat Petalangan

\begin{tabular}{clll}
\hline NO & \multicolumn{1}{c}{ NAMA BATIN PETALANGAN } & NO & \multicolumn{1}{c}{ NAMA BATIN PETALANGAN } \\
\hline 1 & Batin Monti Raja & 16 & Batin Tanah Air. \\
2 & Batin Muncak Rantau. & 17 & Batin Tuk Ajo Bilang Bungsu. \\
3 & Batin Putih. & 18 & Batin Pelabi. \\
4 & Batin Hitam. & 19 & Batin Mudo Langkan. \\
5 & Batin Pematang. & 20 & Batin Antan-antan Diajo. \\
6 & Batin Tuan Apuh. & 21 & Batin Gengeng. \\
7 & Batin Mudo Genduang. & 22 & Batin Gasip. \\
8 & Batin Sengiri Komang. & 23 & Batin Rantau Baru. \\
9 & Batin Bunut. & 24 & Batin Mudo. \\
10 & Batin Telayap & 25 & Batin Baru (Bau). \\
11 & Batin Sungai Buluh. & 26 & Batin Panghulu Besar. \\
12 & Batin Tomo Payung. & 27 & Batin Delik. \\
13 & Batin Badu Ondo & 28 & Batin Kerinci. \\
15 & Batin Sulo Dilaut & 29 & Batin Panduk
\end{tabular}

\section{Struktur Kelembagaan Adat Petalangan}

Masyarakat merupakan suatu kesatuan hidup manusia yang saling berhubungan antara satu sama lainya secara terus menerus yang terikat oleh kebiasaan dan identitas bersama. Kehidupan masyarakat dapat dikatakan sebagai sistem sosial oleh karena di dalam masyarakat terdapat unsur-unsur sistem sosial. Secara garis besar, unsur-unsur sistem sosial dalam masyarakat adalah orang-orang yang saling bergantung antar satu sama lainnya dalam suatu keseluruhan dan lingkungan.

Dalam ketergantungan itu sekumpulan manusia terintegrasi yang bersifat lebih kekal dan stabil. Selama masing-masing individu dalam kelompok masyarakat itu masih saling tergantung dan masih memiliki kesamaan dan keseimbangan prilaku, maka selama itu pula unsur -unsur sistem sosial menjalankan fungsinya. Sedangkan secara khusus dan rinci, sistem sosial dalam masyarakat adalah status, 
peranan perbedaan sosial dari individu-individu yang saling berhubungan dalam suatu struktur sosial

Pimpinan Suku Petalangan antara lain Patih, Batin, Monti dan Dubalang. Masingmasing pimpinan mempunyai hak dan wewenang yang jelas seperti pengurusan hukum adat, pengurusan wilayah adat. Sejarah lahirnya pimpinan ini tidak terlepas dari Patih nan Sebatang, pada mulanya kepemimpinan suku hanya ada Patih, Batin dan Dubalang tetapi karena melihat alam semakin luas semakin banyak maka patih merelakan untuk membentuk Monti dan Penghuku dibawah kepemimpinan batin dan wilayah pesukuan. Untuk memahami bagaimana struktur kepemimpinan masyarakat Petalangan, berikut disajikan bagan alur

Struktur adat sebagaimana digambarkan di atas sampai sekarang masih berfungsi dan berperan, namun ada beberapa hal sudah mengalami perubahan kekuasaan, selanjutnya untuk memahami lebih rinci tentang peran-peran pemimpin dalam masyarakat Petalangan berikut disajikan deskripsinya:

1. Sultan Pelalawan, bertugas mengatur dan memelihara hukum dalam kerajaan sesuai dengan undang-undang yang dibuatnya

2. Patih adalah pucuk pimpinan tertinggi dari silsilah adat Suku Petalangan, patih mempunyai wewenang tidak terbatas dan mempunyai hak atas segala kepemilikan alam Suku Petalangan di manapun berada. Seorang Patih adat Petalangan harus berasal dari suku Petalangan dengan garis keturunan dari Ibu kandung, dan berhak menerima gelar Patih adalah kemenakan dari Patih.

3. Batin merupakan pimpinan tertinggi di wilayah persukuan, hak dan kewenangannya berkaitan dengan adat dan bahkan urusanurusan pemerintahan, batin menjadi pemimpin di antara anggotanya dalam komunitas

4. Ketiapan berperan juga dalam masyarakat terutama dalam urusan-urusan adat . Ketiapan menjadi tangga pertama dalam urusan-urusan adat. Anggota Batin yang hendak menyelenggarakan upacara adat pertama-tama harus berbicara dengan ketiapan baru kepada Batin.

5. Monti, merupakan jabatan terndah yang berhubungan langsung dengan masyarakat. Tugasnya menerima pengaduan masyarakat dan menjalankan perintah adat yang ditetapkan Batin dan Ketiapan

6. Dubalang, bertindak sebagai lembaga yudikatif yang memberikan sanksi dan denda atas pelanggaran berdasarkan kesepakatan dengan Batin

7. Kemantan, Dukun adalah orang yang pandai melakukan berbagai upacara magis, dan konsultan dalam kegiatan yang dilaksanakan Batin.

Orang-orang tua lazimnya mengatakan "bagaikan teluk timbunan kapar, bagaikan tanjung pumpunan angin, duduknya tempat berguru, tegaknya tempat bertanya" atau dikatakan juga "pucuk jala pumpunan ikan , yang berambai panjang bersayap lebar, tenangnya tempat berlabuh, teduhnya tempat berhenti". Melalui ungkapan, pepatah-petitih diatas jelaslah sudahh akan tingginya kedudukan batin dalam masyrakat petalangan, dimana bain menjadi acuan dari masyarakat petalangan sebagai tempat untuk bertanya,dan menyelesaikan masalah.

\section{Kajian Terhadap Nilai-nilai dan Hukum Masyarakat Adat Petalangan}

Hukum adat secara umum adalah hukum yang tidak tertulis di dalam peraturan-peraturan legislatif (unstatutory law) meliputi peraturanperaturan hidup yang ditaati oleh masyarakat berdasarkan keyakinan bahwa peraturan itu mempunyai kekuatan hukum. Prinsip memegang adat sangat kuat bagi masyarakat Petalangan dan cenderung menolak budaya luar, Penuturan Batin Hitam suku Petalangan " biar mati anak asal jangan mati adat". Artinya kekukuhan memegang adat masih kuat bagi masyarakat Petalangan.

Adat dan aturan menjadi simbol bagi masyarakat Petalangan dalam menjalankan adat dan budaya termasuk didalamnya ketika menyelesaikan masalah pada komunitas masyarakat Petalangan. Lahirnya aturan adat berpijak pada adanya kesamaan dan kesepahaman berjenjang naik bertangga turun (turun-temurun) dari leluhur Masyarakat Petalangan. Hukum dan sanksi adat dapat dilihat pada tabel 2 berikut : 
Tabel 2. Hukum dan sanksi adat masyarakat Petalangan.

\begin{tabular}{|c|c|c|}
\hline $\begin{array}{c}\text { Hukum dan Sanksi } \\
\text { Adat } \\
\end{array}$ & Jenis Kesalah & $\begin{array}{c}\text { Bahan dan Alat-alat Dalam Sanksi } \\
\text { Adat }\end{array}$ \\
\hline Iingan & $\begin{array}{l}\text { Mendirikan Perkampungan, dusun, } \\
\text { bangunan, bercocok tanam (menduduki) } \\
\text { tanah tanpa izin dari yang punya seperti } \\
\text { ketua adat, batin. }\end{array}$ & $\begin{array}{l}>\text { Mangkuk } 2 \text { buah } \\
>\quad \text { Tempat sirih } \\
>\quad \text { Pinggan } 6 \text { buah } \\
>\quad \text { Beras } \\
>\quad \text { Koiam }(\text { Keris / Senjata) }\end{array}$ \\
\hline Ringan Sodang & $\begin{array}{l}\text { Membakar dengan sengaja tanaman yang } \\
\text { tidak menghasilkan buah seperti: meranti, } \\
\text { balam, kempas, kulim, sungkup, medang, } \\
\text { sanduk-sanduk, dll }\end{array}$ & $\begin{array}{l}>\text { Mangkuk } 3 \text { buah } \\
>\quad \text { Pinggan } 6 \text { buah } \\
>\quad \text { Tempat sirih } \\
>\quad \text { Aeras } \\
>\quad \text { Kois (Keris / Senjata) }\end{array}$ \\
\hline Sodang Petamo & $\begin{array}{l}>\text { Mencuri tanaman menghasilkan buah } \\
\text { Membakar Pohon durian, kedondong, dan } \\
\text { kepayang } \\
\text { Mencuri, menumbang dan membakar tanaman } \\
\text { yang tidak menghasilkan buah } \\
>\quad \text { Mencuri buah-buahan }\end{array}$ & $\begin{array}{ll}> & \text { Mangkuk } 4 \text { buah } \\
> & \text { Pinggan } 18 \text { buah } \\
> & \text { Beras } 10 \mathrm{Kg} \text { atau } 3 \text { gantang } \\
> & \text { Ayam (sesuai kemampuan } \\
> & \text { Kois (Keris / Senjata) }\end{array}$ \\
\hline Sodang Keduo & 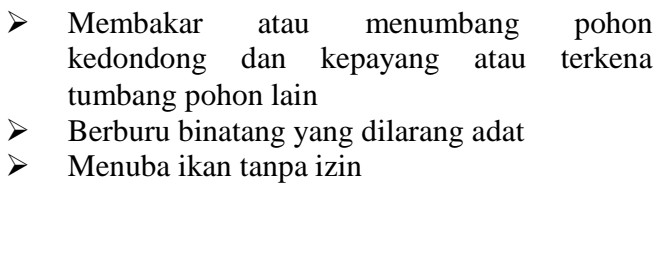 & $\begin{array}{ll}> & \text { Mangkuk } 6 \text { buah } \\
> & \text { Pinggan } 23 \text { buah } \\
> & \text { Tempat sirih } \\
> & \text { Ayam } \\
> & \text { Kain } 36 \text { lembar } \\
> & \text { Kois (Keris / Senjata) } \\
> & \text { Gelang perak }\end{array}$ \\
\hline $\begin{array}{l}\text { Boat (berat) } \\
\text { Petamo }\end{array}$ & $\begin{array}{l}\text { Mencuri, menebang, mengambil dan merusak } \\
\text { di rimba larangan. }\end{array}$ & $\begin{array}{l}\text { Uang } 12 \text { juta dan ditambah pohon } \\
\text { sialang }\end{array}$ \\
\hline $\begin{array}{l}\text { Boat } \\
\text { Keduo }\end{array}$ & $\begin{array}{l}\text { Mencuri, Menebang dan mengambil Pohon } \\
\text { sialang }\end{array}$ & $\begin{array}{l}>\text { Kain putih sepanjang pohon } \\
\text { sialang } \\
>\quad \text { Kobau atau 7 Kambing }\end{array}$ \\
\hline
\end{tabular}

Sumber : data olahan peneliti 2016

Keberadaan hukum adat sangat penting dan diakui, tetapi dalam perkembangannya ada kecenderungan pemahaman terhadap hukum adat kian hilang dimasyarakat bahkan dalam masyarakat dimana hukum adat itu tumbuh dan berkembang. Kondisi serupa tidak terkecuali terhadap adat dan istiadat dan hukum adat pada masyarakat Petalangan. Adanya banyak faktor penyebab hal itu terjadi bahkan ditengah masyarakat Petalangan.

Ketentuan hukum ini tidak dapat berubah-ubah hal ini tergambar Batin "siapa menconcang di concang, siapa membunuh di bunuh" dengan pertimbangan orang bertambah ramai dan dunia bertambah luas maka ditetapkanlah tingkatan-tingkatan hukum.
Hukuman adat tertinggi adalah hukuman adat boat dan serendah-rendahnya adalah hukuman ingan.

Aturan-aturan yang dibuat oleh masyarakat Petalangan disamping secara tertulis juga ada dalam bentuk petatah-petitih, adat yang diturun-temurun melalui petatah-petitih aakan disampaikan ketika acara adat diperingati/ diperdengarkan kepada anak-kemenakan. Hukum adat yang banyak diatur secara tertulis yaitu yang berhubungan dengan pengelolaan sumberdaya alam seperti sungai hutan dan lahan.

Tumbuhan yang menghasilkan buah maupun yang tidak diatur dalam sanksi hukum adat untuk tumbuhan yang menghasilkan buah 
sudah jelas diatur dengan adat, laranganlarangan tersebut adalah jika menginginkan buah dari tumbuhan dari tumbuhan tersebut haruslah meminta izin kepada pemiliknya, tidak boleh menebang, membakar sekitar tanaman tersebut. Tumbuhan yang tidak menghasilkan buah banyak juga dijumpai di kawasan hutan masyarakat Petelangan, tumbuhan ini menghasilkan nilai ekonomis tinggi baik digunakan untuk kepentingan pembangunan rumah, acara adat, dan dijual. Walaupun tumbuh secara liar di alam bebas tetapi juka sudah termasuk dalam kawasan hutan masyarakat Petalangan wajib hukumnya dipelihara. jika kita ingin mengambilnya haruslah meminta kepada pemangku adat diwilayah adat pesukuan. jika pengambilan tanpa sepengetahuan pemangku adat pada wilayah adat pesukuan akan dikenakan sanksi.

Hal inilah yang selama ini nyaris tidak pernah diperhatikan apalagi dipahami oleh masyarakat yang tidak tahu. Masyarakat yang tidak mendalami kebudayaan masyarakat Petalangan selalu beranggapan bahwa hutan tanah hanyalah bermanfaat jika diolah dibuat kebun, ladang , dan sebagainya, yakni untuk kepentingan ekonomi saja. Padahal, bagi masyarakat Petalangan hutan tanah bukanlah semata mata untuk memenuhi kebutuhan hidup lahiriah, tetapi juga menjadi sumber keperluan hidup batiniahnya. Bahkan, hutan tanah dijadikan contoh teladan sebagai sumber falsafah dan acuan moral kehidupan mereka. Mereka memeliki ketentuan adat istiadat untuk tetap memelihara kelestarian alam lingkungannya, yang sudah mereka buktikan selama ratusan tahun.

Tradisi ladang berpindah yang dilakukan masyarakat Petalangan seringkali dijadikan kambing hitam karena dianggap merusak hutan tanah dan habitatnya, namun sebenarnya anggapan tersebut amatlah keliru. Bagi masyarakat Petalangan, area tempat perladangan berpindah itu sudah diatur menurut adat mereka, sehingga berpindahan itu tidaklah keluar dari tata batas yang telah ditetapkan adatnya. Didalam area itulah mereka berpindah yang sirkulasinya terjadi antara 5- 10 tahun. Area yang disediakan untuk berladang itu disebut tanah perladangan. (wawancara : Tokoh Masyarakat Air Hitam, pada tanggal 26 September 2012)

\section{Sanksi Adat}

Penerapan sanksi-sanksi adat ini pernah dilakukan terhadap disalah satu kasus sebagaimana diutarakan oleh Yunus Syam (wawancara : tokoh adat 15 Maret 2013), berdasarkan keputusan musyawarah batin dan tokoh adat masyarakat Petalangan pada tahun 2006 telah dijatuhkan sanksi kepada sebuah perusahaan Rp. 150. 000.000 ( Seratus Lima Puluh Juta Rupiah) setelah perusahaan tersebut melakukan penebangan beberapa jenis pohon sialang yang berada dalam kawasan masyarakat Petalangan. Sebelum sanksi di tetapkan terhadap si pelanggar terlebih dahulu dilakukan penyelidikan oleh para batin.

Menurut Batin Bunut pelanggaran terbagi kepada dua kategori yakni (1) Pelanggaran yang dilakukan oleh induvidual (2) Pelangaran yang dilakukan oleh Pebatinan (kelembagaan). Pelanggaran induvidual adalah pelanggaran yang dilakukan oleh seseorang dan tidak ada yang menyuruhnya untuk melakukan pelanggaran tersebut. Sedangkan pelanggaran dalam kategori pebatinan (kelembagaan) adalah pelanggaran yang dilakukan oleh seseorang atau beberapa orang yang diperintahkan oleh salah satu pebatinan atau lembaga lainnya baik oleh batin maupun oleh lembaga lainnya tersebut.

Proses pemeriksaan terhadap pelanggaran merusak lingkungan masyarakat Petalangan yakni, Pertama dimulai dari indentifikasi si pelanggarnya, apakah bersifat induvidual atau perbatinan. Kedua apa alasan seseorang/ pebatinan melanggar. Ketiga apa bentuk pelanggaran yang dilakukannya. Keempat apa bentuk pelanggaran yang dilakukannya. Kelima jenis sanksi yang diberikan kepada si pelangar. Keenam Siapa saja saksi-saksinya.

\section{Pendekatan Simbolik}

Tanah ulayat yang menjadi simbol marwah dan tuah negeri masyarakat Petalangan, hal ini tersurat dinyatakan dalam tombo adat " Kelaut bebungo koang, kedaat bebiji omping". Makna tombo tersebut bahwa bukti adanya wilayah adat, yaitu kawasan laut dan daratan merupakan simbol keeksistansian kekuasaan dan marwah adat mereka itu sendiri. Menurut mereka kekuasaan wilayah adat itu ada dua macam. Pertama wilayah perairan. Kedua wilayah daratan. Pengungkapan kata-kata 
wilayah perairan dalam adat istilah dengan perkataan laut. Kata laut bukan makna sebenarnya tetapi makna majaziyah atau simbolik (kiasan) maksudnya adalah wilayah perairan sungai Kampar..

Makna kata-kata "Bebungo koang" sebagaimana terdapat dalam tombo adat mengandung makna simbolik. Kata Koang (hewan kerang) melambangkan ketegaran, kekuatan dan konsistensi. Ia hidup didalam laut secara alami namun memiliki sifat yang keras dan selalu berkembang bagaimanapun keras ombak air laut. Sifat hewan kerang ini hendaklah dapat dijadikan tauladan bagi masyarat Petalangan untuk meraih kehidupan harus memiliki semangat yang kuat tidak cepat menyerah waupun dihantam gelombang serta tetap optimistis walaupun bergerak sangat lamban sebagaimana gerakan pertumbuhan karang yang begitu sangat lambat namun demikian ia harus tetap berkembang dan tumbuh. Didalam tombo adat juga dikatakan " kedaat bebiji omping" . Makna kata daat dalam masyarakat Petalangan mengandung dua tafsiran. Pertama kata daat dalam pengertian menunjukan suatu kawasan daratan. Kedua kata daat dalam pengertian menunjukan suatu arah kawasan yaitu suatu kawasan diluar perkampungan yang terletak agak jauh dari perkembangan penduduk misalnya kawasan yang bersepandan dengan hutan. ungkapan kedaat mendapat omping menunjukan simbol kekuasaan batin adat bukan saja di aliran Sungai Kampar tetapi juga di daerah atau kawasan daratan yang jauh dari Sungai Kampar.

Sementara itu makna bebiji (memiliki biji) adalah berbekal biji-bijian artinya bahwa dalam kehidupan manusia ini manusia harus dibekali dengan sesuatu yang bermanfaat. Kehidupan bukan sesuatu yang sudah tersedia begitu saja, melainkan suatu proses dan perlu perencanaan sebagaimana yang terkandung dari kata bebiji (memiliki biji) pada ungkapan dalam tombo tersebut. Maksud lain dari tamsilan kata bebiji ialah manusia hidup harus mempersiapkan diri serta membawa bekal yang dapat bermanfaat bagi kehidupan manusia lainnya walaupun hanya satu biji omping.

Kata Omping menunjukkan dua makna . Pertama kata omping mengandung ungkapan perbekalan untuk keutamaan hidup. hal ini disimbolkan dengan makna omping dari padi muda. Omping merupakan simbol keberhasilan panen padi serta menandakan berakhirnya musim padi. Sudah menjadi kebiasaan masyarakat dahulu apabila mereka berhasil menanam padi maka padi muda yang tersisa tidak dijadikan beras dan dibuat menjadi Omping. Beras itu sendiri merupakan makanan pokok bagi masyarakat Petalangan. Kedua kata omping merupakan tamzilah yang mengandung ajaran bahwa hidup tidak boleh sia-sia. Hal ini disimbolkan dengan kata omping yaitu sejenis makanan kerupuk yang terbuat dari buah malinjo maknanya bahwa dalam kehidupan manusia harus selalu membekali dirinya walaupun hanya dengan satu biji melinjo

\section{PEMBAHASAN}

Ada beberapa aspek sosial yang mempengaruhi posisi kekerabatan seseorang dengan orang lain. Dalam hal ini, bila diamati dalam tatanan kehidupan masyarakat adat Petalangan (pebatinan kuang oso tigo pulou) menempatkan seseorang dalam interaksi sosial sesuai dengan relasi kekerabatannya. Relasi kekerabatannya itu pertama, berdasarkan relasi geneologis atau biologis dan kedua, berdasarkan relasi ideologis.

Pertama, kekerabatan berdasarkan relasi (hubungan) geneologis yaitu hubungan kedekatan ego (seseorang) yang ditarik secara horizontal maupun vertikal. Secara horizontal, misalnya hubungan saudara kandung atau hanya seibu atau hanya sebapak termasuk dengan anak-anak dari saudara bapak dan saudara ibu yang kandung maupun yang seibu atau yang sebapak. Relasi keluarga yang terdiri dari ayah, ibu dan anak-anak termasuk dalam kelompok keluarga inti. Hubungan pernikahan antar keluarga ini akan membentuk keluarga luas. Misalnya seseorang dari kelompok melakukan hubungan pernikahan dengan kelompok yang lain, maka posisi laki-laki bersama keluarganya menjadi keluarga pihak perempuan, demikian juga sebaliknya.

Hubungan Vertikal berupa hubungan orang tua dengan anaknya termasuk dengan kakek/nenek, moyang hingga tingkatan nenek moyang beserta saudara-saudara dari setiap tingkatan silsilah. Hubungan seperti ini dalam wilayah budaya masyarakat Petalangan dan melayu pada umumnya lebih dikenal dengan istilah keluarga (family) atau kaum. 
Kedua kekerabatan berdasarkan relasi ideologis yaitu orang-orang yang secara sosial berhimpun dalam suatu klen (suku) tertentu. Penempatan seseorang masuk dalam suku berdasarkan aturan adat yang berlaku dalam kelompok masyarakat. Mengikuti aturan adat seseorang bisa saja bukan masuk dalam kerabat bapaknya atau kerabat ibunya. Misalnya dalam budaya patrilineal, seorang anak adalah kerabat dari bapaknya dan bukan kerabat dari ibunya. Sebaliknya mengikuti sistem matrilineal seorang anak adalah kerabat dari ibunya dan bukan keraba dari bapaknya.

Berbeda dengan hal sebelumnya Misnal Munir (2015) mengatakan perbedaan sistem kekerabatan patrilineal yang dianut oleh sebagian besar kebudayaan dunia yang menjadikan wanita sebagai sarana komunikasi antarklen atau suku, kebudayaan Minangkabau yang menganut sistem matrilineal justru menjadikan laki-laki sebagai sarana komunikasi antar klen atau suku. Inisiatif perjodohan dalam perkawinan menurut adat Minangkabau datang dari pihak perempuan untuk melamar pihak laki-laki. Mamak pihak laki-laki akan melakukan penjajakan dengan mamak pihak perempuan untuk menjodohkan kedua kemenakan mereka.

Sistem kekerabatan ini memperkuat budaya dari dalam, karena merasa satu garis keturunan dan dalam satu masayarakat yang mempunyai kepentingan yang sama maka masyarakat Pertalangan merasa tanah, sungai dan rimbo harus dijaga karena milik bersama sesuai dengan rasa kekerabatan yang dimiliki oleh masyarakat Petalangan sehingga dapat di turunkan dan dirasakan oleh garis keturunan berikutnya.

Prinsip utama masyarakat Petalangan dalam memandang dan berhubungan antar sesama dengan menanamkan sikap "Seasal dan Semoyang". Penanaman prinsip ini menyebabkan terjadinya ikatan diantara mereka sebenarnya bersaudara. Untuk saling menghargai antara sesama masyarakat, baik dengan yang seadat maupun dengan pihak luar, mereka menanamkan sikap " yang tua di hormati, kawan sebaya dihargai dan yang muda disayangi". Itulah sebabnya orang yang masih muda dalam menyapa yang lebih tua tidak pernah menyebut nama, bahkan orang tua-tua pun sangat jarang menyebut nama orang yang lebih muda.
Kebiasaan menyapa dengan menyebut nama hanya terjadi dengan kawan sebaya. Tetapi bila kawan sebaya ataupun yang lebih muda sudah dituakan dalam adat, dalam arti diberi amanah memegang jabatan perangkat adat, orang tersebut akan disapa dengan menyebut gelar adatnya.

Rahmad,S (2008) mengatakan kelompok etnis yang mempunyai kedekatan budaya, maka prasangka sosial yang terjadi lebih mengarah kepada prasangka positif dan jarak social yang dekat. Sebaliknya, bagi kelompok etnik yang mempunyai corak budaya yang berbeda jauh dengan etnik lainnya, maka di antara mereka terdapat prasangka sosial yang bercorak negatif dan jarak sosial yang amat jauh. Namun demikian, meskipun adanya prasangka sosial negatif dan jarak sosial yang jauh antara mereka tetap dapat terjalin kerjasama teruatama dalam kegiatan yang bersifat sosial.

Dalam masyarakat petalangan Batin memiliki fungsi untuk menjaga tanah ulayat yang menjadi tanda marwah suatu suku di masyarakat petalangan. Ada pun yang menjadi dasar bagi batin untuk menjaga tanah ulayat adalah berdasarkan tombo pesukuan yang berisi tentang sejarah tanah ulayat dan batas-batasnya Secara normatif peranan batin dalam harta pusaka dapat kita lihat dalam ungkapan berikut ini Mulia umat bertanah ulayat Tanah adat tanah pusaka Tanah soko turun temurun Tanah pantang dijual gadai. Tanah pantang dirusak dibinasakan Tanah pantang dibuang-buang Kalau memakai ada adatnya Kalau menumpang ada undangnya2 . Ungkapan diatas menjelaskan akan nilai dari harta pusaka, baik.harta soko maupun harta pusako, dan menjadi tugas batinlah untuk menjalankan segala hal yang bersangkutan dengan harta pusaka.

Pergeseran adan dan kepemimpinan adat yang terjadi di tengah masyarakat Petalangan memang sudah tampak seiring dengan perkembangan zaman yang semakin cepat, apalagi dengan diberlakukannyaUndang-undang No.5 Tahun 1979 tentang Pemerintanhan Desa (walaupun Undang-undang ini kemudian diganti dengan Undang-undang No. 22/1999 dan kemudian direvisi lagi menjadi UU No.32/ 2004), maka Undang-undang ini telah banyak mengurangi peranan Batin sebagai ketua adat dan pemimpin masyarakat Petalangan. Kendatipun demikian Batin dalam masyarakat Petalangan tetap ada 
dan berjalan dengan fungsinya. Komunitas Suku Petalangan mempunyai hirarki dan struktur adat yang jelas, dan dijalankan sepenuhnya oleh masyarakat Petalangan yang masih menganut langkah lama atau masyarakat dengan kepercayaan terhadap mitos-mitos.

Hubungan sosial antara batin-penghulu, pesukuan yang satu dengan yang lainnya merupakan hubungan saling menghargai dan menghormati. Batin yang satu tidak akan turut campur dalam mengurus persoalan yang terdapat dalam batin lainnya, demikian pula dengan mamak suku yang satu tidak pula turut campur dalam urusan rumah tangga pesukuan lainnya kecuali atas permintaan yang dibenarkan secara adat

Tidak ada perbedaan komunitas kelompok batin ataupun kelompok suku yang satu dengan yang lainnya. Keseluruhan batin-pengulu yang ada menempatkan suatu batin sebagai penyeimbang hubungan sosial antar pebatinankepenghuluan bergelar Rajo Bilang Bungsu. Fungsi utama Rajo Bilang Bungsu untuk mengorganisir hubungan keseluruhan batinpenghulu.

Pola kehidupan masyarakat berdasarkan kelompok-kelompok suku, tidak membatasi ruang gerak anggota pesukuannya, karena mereka memegang sikap saling menghargai. Atas kesadaran bahwa mereka seasal dan semoyang menumbuhkan pula sikap tolong menolong dan solidaritas yang tinggi sesama masyarakat. Solidaritas dan sikap tolong menolong itu dapat dilihat ketika terjadi perhelatan pernikahan anak kemenakan dalam suatu suku, maka semua masyarakat adat akan memberikan sumbangan sesuai dengan kemampuan masing-masing.

Terhadap kaum pendatang, sesunggunya masyarakat Petalangan sangatlah terbuka, bila ada kaum pendatang yang ingin bekerja dan menjadi penduduk tetap, orang - orang patut dalam adat akan memberitahukan syarat untuk menetap di kampung tersebut. syarat yang harus dipenuhi yaitu menyangkut prilaku, sebagaimana dalam pepatah adat mensyaratkan, di mana bumi di pijak di situ langit di junjung, dimana air di suak di situ ranting di patahkan. Artinya para pendatang yang mau menetap harus mengikuti aturan adat setempat, dan jika memperoleh kekayaan dari usahanya harus pula menanamkan sebagian kekayaannya di kampung tersebut.

Posisi kaum pendatang bisa pula menjadi masyarakat adat setempat dengan syarat kaum pendatang tersebut mencari mamak suku. mencari mamak suku sama artinya menyerahkan diri untuk masuk dalam suku yang dipimpin oleh mamak suku tertentu. Terutama untuk pendatang yang adat resamnya berbeda dengan sistem adat di Petalangan yang mempunyai hajat untuk menikah dengan anak-kemenakan masyarakat adat Petalangan diharuskan mencari mamak suku. ini diperlukan, agar pernikahan dapat diselenggarakan secara adat. lebih luas kegunaan kaum pendatang masuk suku selain sebagai pengakuan bahwa yang bersangkutan sudah menjadi anak kemenakan dalam masyarakat adat, juga sebagai jalan mempermudah berinteraksi dan bersosialisasi dalam tatanan sosial yang berlaku sehari- hari

Orang Petalangan yang sudah dewasa tentulah ada yang hidup dan menetap di tempat orang lain. Kepada anak kemenakan yang memilih hidup di negeri orang (perantauan) selain ditanamkan sebagaimana aturan yang diberikan pada para pendatang ke kampungnya, ditanamkan pula sikap rendah hati itu mengikuti ungkapan adat, duduk di bawah -bawah, mandi di hilir-hilir. Ungkapan tersebut mengingatkan untuk bersikap tahu diri sebagai perantau, janganlah membusungkan dada dan berlaku sombong di negeri orang.

Tatanan hubungan sosial masyarakat adat perbatinan di Petalangan mempunyai tujuan yang jelas yaitu terciptanya kehidupan saling pengertian. Jika seseorang dalam kontak sosial sudah mengerti kedudukannya masing-masing, harapan berikutnya akan terjadi pertukaran dalam bentuk emosional dan tidak menutup kemungkinan dalam bentuk material, Muhammadi (2001). Seseorang secara hirarkhi berada dibawah dengan menghormati dan menghargai hirarkhi yang diatasnya secara inplisit diharapkan hirarkhi yang diatas memberikan imbalan dalam bentuk kasih sayang dan pertolongan lainnya dalam kehidupan. Sebaliknya seseorang yang secara hirarkhi umur ataupun secara senioritas berkedudukan diatas, akan memberikan bantuan / pertolongan dan kasih sayang pada yang dibawahnya, dengan harapan seseorang yang secara hirarkhi berada dibawahnya akan 
menunjukan sikap menghormati dan menghargainya. Sikap saling pengertian seperti ini yang menyebabkan terjadinya kehidupan yang damai dalam masyarakat Petalangan.

Menurut Abubakar (2012) Kabupaten Bireuen secara teoritis telah berusaha memaksimalkan peran lembaga adat, salah satunya adalah Keujreun Blang, lembaga adat ini disebut sebagai P3AI (yaitu Perkumpulan Petani Pemakai Air) pengelompokkan petani dalam wadah ini adalah untuk menyelaraskan perkumpulan petani sawah secara nasional, meskipun perkumpulan seperti ini dapat mengurangi makna lembaga adat.

Tenas (2008) mengatakan Setiap anggota masyarakat dilarang membuat ladang di luar areal itu, bahkan pelanggaran akan dihukum menurut ketentuan hukum adat tempatan. Dengan demikian jelas bahwa masyarakat Petalangan bukanlah perusak hutan tanah, bahkan merekalah sebenarnya penyelamat hutan tanah, karena mereka sudah mengatur pemanfaatan hutan tanah menurut acuan adat.

Salah satu bentuk norma adat melindungi Sungai, Tanah dan rimbo masyarakat Petalangan Pelalawan adalah melalui sanksi adat. Istilah sanksi adat dalam masyarakat Petalangan sudah dikenal sejak dahulu kala sehingga menjatuhkan sanksi adat merupakan sesuatu hal yang bukan dianggap tabu atau terlarang. Walaupun sanksi adat sudah dikenal sejak dahulu kala namun dalam penerapannya dalam tombo adat secara arif dikatakan. "Tak ado salah tak betimbangkan, Beutang Bebayo, Salah Makan dimuntaan, Salah ambik di balikkan" (Tidak ada salah yang tidak diperhitungkan, kalau ada hutang harus dibayar, salah makan dimuntahkan, salah ambil dikembalikan. Seseorang bisa saja tidak dijatuhkan sanksi adat apabila yang seseorang itu baru pertama kali berbuat salah dan jenis kesalahannya tidak berakibat fatal serta karena ketidaktahuan dia terhadap suatu perkara tersebut. Untuk menjamin kelestarian Lingkungan dalam masyarakat Petalangan, maka dijatuhkan sanksi adat bagi mereka yang mengambil kayu atau merusak lingkungan adat Petalangan dengan sengaja.

Norma merupakan aturan atau panduan dalam aktivitas. Norma merupakan ukuran yang digunakan oleh masyarakat apakah tindakan yang dilakukan oleh seseorang atau kelompok orang merupakan tindakan yang wajar dan dapat diterima karena sesuai dengan harapan sebagian besar warga masyarakat ataukah merupakan tindakan yang menyimpang karena tidak sesuai dengan harapan sebagian besar warga masyarakat (Angsa, 2009). Melalui norma kelestarian lingkungan dilindungi dan eksploitasi alam secara berlebihan. Melalui norma sosial masyarakat dihimbau, diajar serta dibiasakan bagaimana menjalin hubungan yang harmonis dengan alam dan makhluk lainnya.

Dalam hukum adat masyarakat Petalangan, lembaga adat memiliki wewenang menyelesaikan kasus-kasus adat maupun membentuk hukum adat. Lembaga adat di sini adalah dalam pengertian forum bukan perorangan yang secara tidak sengaja ada untuk menangani ketidakadilan dan keluhan warga, penggunaan kata aturan atau prinsip mengindikasikan bahwa akses kepada keadilan memerlukan aturan atau prinsip yang memandu prosedur menuju hasil (Bedner dan Vel, 2009). Meski demikian, efektitivitas lembaga adat sebagai forum juga ditentukan oleh peranan tokoh adat, baik dalam kedudukan menjadi perantara pengaduan masyarakat adat ke forum yang lain, seperti pemerintah desa, kecamatan dan kabupaten, juga dalam perilaku individual yang memberikan contoh dan panutan bagi warga adat. Untuk kedudukan yang terakhir ini, Nixen memberi gambaran spesifik mengenai kriteria orang-orang yang mengisi lembaga adat di Marena, antara lain keteladanan, moralitas, kemampuan merumuskan hukum adat agar dapat diterima masyarakat.

\section{SIMPULAN}

Sistem kekerabatan memperkuat budaya dari dalam, karena merasa satu garis keturunan dan dalam satu masayarakat yang mempunyai kepentingan yang sama maka masyarakat Pertalangan merasa tanah, sungai dan rimbo harus dijaga karena milik bersama sesuai dengan rasa kekerabatan yang dimiliki oleh masyarakat Petalangan sehingga dapat di turunkan dan dirasakan oleh garis keturunan berikutnya, Dalam pergaulan hidupnya, masyarakat adat Petalangan menduduki sebuah wilayah yang masing-masing pebatinan memiliki wilayah tersendiri.Wilayah tersebut biasa disebut ulayat.Dalam kebiasan adat 
dikenal pengaturan tentang pemanfatan yang berkaitan dengan lingkungan.

Orang Petalangan yang sudah dewasa tentulah ada yang hidup dan menetap di tempat orang lain. Kepada anak kemenakan yang memilih hidup di negeri orang (perantauan) selain ditanamkan sebagaimana aturan yang diberikan pada para pendatang ke kampungnya, ditanamkan pula sikap rendah hati itu mengikuti ungkapan adat. Hukuman adat tertinggi adalah hukuman adat boat dan serendah-rendahnya adalah hukuman ingan. Proses pemeriksaan terhadap pelanggaran merusak lingkungan masyarakat Petalangan yakni, Pertama dimulai dari indentifikasi si pelanggarnya, apakah bersifat induvidual atau perbatinan. Kedua apa alasan seseorang/ pebatinan melanggar. Ketiga apa bentuk pelanggaran yang dilakukannya. Keempat apa bentuk pelanggaran yang dilakukannya. Kelima jenis sanksi yang diberikan kepada si pelangar. Keenam Siapa saja saksi-saksinya. Tanah ulayat yang menjadi simbol marwah dan tuah negeri masyarakat Petalangan, hal ini tersurat dinyatakan dalam tombo adat. Pengungkapan kata-kata wilayah perairan dalam adat istilah dengan perkataan laut. Kata laut bukan makna sebenarnya tetapi makna majaziyah atau simbolik (kiasan) maksudnya adalah wilayah perairan sungai Kampar.

\section{UCAPAN TERIMA KASIH}

Pada kesempatan ini penulis mengucapkan terimakasih kepada Lembaga Adat Petalangan, Pemerintah Pelalawan dan Masayarakat Adat Petalangan serta tak lupa pula Batin-batin tigopuluh kurang satu oso yang telah banyak membantu dalam penulisan ini.

\section{DAFTAR PUSTAKA}

Abubakar, 2012 Peran Lembaga Adat Kujreun Blang dalam Peningkatan Kesejahteraan Petani sawah di Kabupaten Bireueun. Jurnal Pendidikan dan Pembinaan Umat, Vol 1 No.6

Angsa, 2009, Nilai dan norma social, http://angsasman3ykwordpress.com/2009/ 09/01nilai-dan-norma-sosial/,

Bedner,Adrian\&Vel,Jacqueline.2009.AccesstoJ usticeandRuleofLaw,ConceptualPaperNo.
1,Van Vollenhoven Institute -Access to Justice in Indonesia, Faculty of Law, Faw - Laiden University

Maskar Herman, 2009 Nyanyian Panjang Sutan Pominggie, Tradisi Lisan Orang Petalangan Riau. Gurindam Pres, DKP Pelalawan

Misnal Munir, Sistem Kekerabatan dalam Kebudayaan Minangkabau Perspektif Aliran Filsafat Strukturalisme Jean Claude Levi-Strauss, Jurnal Filsafat Vol. 25 No. 1

Muhammadi, at.al, 2001.Analisis System

Dinamis Lingkungan Hidup, Sosial, Ekonomi, Manajemen.UMJ Press, Jakarta

Rachmad.S, 2008. Kearifan Lokal Pada Masyarakat Adat di Indonesia. Publica Vol IV No.01 2008 hlm 8-15 Vol IV

Tenas.E, 1997. Bujang Tan Domang: Sastra Lisan Orang Petalangan. Yayasan Bentang Budaya; Yogyakarta

UNDP, 2010. UNDP and Indigenous Peoples: A Practice Note on Engagement United States/ United Nation 